\title{
STRATEGI NAFKAH RUMAH TANGGA NELAYAN \\ TRADISIONAL DAN MODERN PADA KOMUNITAS \\ NELAYAN SEKUNYIT, KAUR, PROVINSI BENGKULU
}

\section{Livelihood Strategy of Traditional and Modern Fisheries \\ Household in Sekunyit Fishermen Community, Kaur \\ Bengkulu Province}

\author{
Lidia Yuliana, Septri Widiono, Indra Cahyadinata \\ Jurusan Sosial Ekonomi Pertanian Universitas Bengkulu \\ Email: septriwidiono@unib.ac.id
}

\begin{abstract}
This research aimed to explore the household adaptation of Sekunyit fishermen to the fisheries modernasation in terms of livelihood strategies as a strategy for survival. This research was conducted in the Sekunyit Village, South Kaur District, Kaur regency by using case studies of two traditional fishermen households and two modern fishermen households. It is found that livelihood strategies both of the traditional and modern fishermen includes a multiple sources income, the involvement of family members, and applying their social networks and out-migration as coping strategy. The livelihood strategies conducted in the context of three vulnerability namely the vulnerability of ecology, price system, and single fishery resource were run.
\end{abstract}

Keywords: livelihood strategy, fishermen community

\section{PENDAHULUAN}

Sektor kelautan menjadi salah satu sektor yang sangat diandalkan penduduk Indonesia dalam rangka memenuhi kebutuhan hidupnya, terutama terhadap masyarakat nelayan. Provinsi Bengkulu menjadi salah satu wilayah yang mayoritas penduduknya bekerja sebagai nelayan karena sebagian besar daerah Bengkulu merupakan daerah pesisir. Salah satu daerah pesisir yang berada di Provinsi Bengkulu adalah Kabupaten Kaur. Kabupaten kaur terdiri dari berbagai daerah-daerah pesisir dan mayoritas dari penduduknya bermata pencaharian sebagai nelayan (Dinas Kelautan dan Perikanan Kabupaten Kaur, 2013).

Suatu upaya pemanfaatan sektor kelautan ditempuh melalui modernisasi perikanan tangkap guna meningkatkan kesejahteraan nelayan. Modernisasi sebagai suatu perubahan menuju terbentuknya masyarakat yang kompleks dan terdiferensiasi seiring dengan penerapan ilmu pengetahuan dan teknologi (Schoorl, 1984; Soekanto, 1990) dipandang sesuai untuk memajukan suatu daerah. 
Modernisasi perikanan tangkap terjadi melalui aplikasi teknologi mesin motor (motorisasi) dan alat tangkap (Satria, 2001). Modernisasi perikanan dikenal juga dengan atau revolusi biru (blue revolution) merupakan "jargon" politik sektor perikanan mengikuti succes story revolusi hijau sektor pertanian, dengan target peningkatan efisiensi dan produktivitas perikanan khususnya sumber daya laut (Adri, 2009). Modernisasi dalam pengelolaan sumber daya laut belum seirama dengan peningkatan nasib nelayan tradisional yang diharapkan bertransformasi, menuju perikanan tangkap skala besar.

\begin{tabular}{|c|c|c|c|c|c|}
\hline No & Kecamatan & 2010 & 2011 & 2012 & 2013 \\
\hline 1 & Nasal & 402.070 & 309.334 & 355.374 & 416.209 \\
\hline 2 & Maje & 457.168 & 354.394 & 400.025 & 464.209 \\
\hline 3 & Kaur selatan & 793.978 & 615.487 & 707.810 & 828.136 \\
\hline 4 & Tetap & 41.461 & 32.140 & 39.961 & 43.244 \\
\hline 5 & Kaur Tengah & 214.530 & 166.302 & 191.247 & 223.759 \\
\hline 6 & Semidang Gumay & 248.460 & 192.563 & 221.447 & 259.094 \\
\hline 7 & Lukang Kule & 141.087 & 125.776 & 147.157 & 109.370 \\
\hline & Jumlah & 2.298 .709 & 1.779 .590 & 2.039 .000 & 2.381 .900 \\
\hline
\end{tabular}

Sumber: Dinas Kelautan dan Perikanan Kabupaten Kaur, 2013

Meskipun demikian modernisasi perikanan tangkap belum mampu menjadikan sektor kelautan sebagai andalan sepenuhnya untuk meningkatkan taraf hidup nelayan. Pendapatan yang relatif masih kecil membuat nelayan sulit untuk menggantungkan hidup sepenuhnya dari sektor kelautan, pendapatan dari melaut tidak bisa dipastikan setiap waktunya dan ditambah lagi dengan datangnya cuaca buruk. Di tingkat rumah tangga taraf hidup dapat dilihat melalui strategi nafkah (livelihood strategy). Livelihood strategy merupakan proses-proses di mana rumah tangga membangun suatu kegiatan dan kapabilitas dukungan sosial yang beragam untuk bertahan hidup dan untuk meningkatkan taraf hidupnya (Swedberg dan Granovetter seperti dikutip oleh Zid, 2011). Ellis (2000) berpendapat livelihood mencakup pendapatan cash (berupa uang) dan in end (pembayaran dengan barang atau hasil bumi) maupun dalam bentuk lainnya seperti institusi (saudara, kerabat, tetangga, desa), relasi gender, dan hak milik yang dibutuhkan untuk mendukung dan untuk keberlangsungan standar hidup yang sudah ada.

Kusnadi (2000) mengungkapkan beberapa pola yang dilakukan oleh nelayan miskin seperti pelibatan anggota keluarga, diversifikasi pekerjaan, dan pemanfaatan jaringan sosial. Studi-studi lain tentang strategi bertahan hidup pada komunitas pedesaan telah mengungkap pola-pola ini diantaranya intensifikasi, ekstensifikasi, nafkah ganda, stradding strategy, dan migrasi (Mardianingsih et al, 2010). Widodo (2011) juga menemukan hal yang sama disamping adanya pelibatan anggota keluarga dan ikatan kekerabatan). Dari latar belakang tersebut penelitian ini bertujuan untuk mengeksplorasi strategi 
nafkah untuk bertahan hidup pada komunitas nelayan di Sekunyit dalam konteks berlangsungnya kerawanan struktural.

\section{METODE PENELITIAN}

Penelitian ini dilaksanakan di Desa Sekunyit Kecamatan Kaur Selatan Kabupaten Kaur, Provinsi Bengkulu. Metode penelitian menggunakan pendekatan kualitatif dengan strategi penelitian studi kasus intrinsik. Studi kasus dilaksanakan pada 2 rumah tangga nelayan tradisional dan 2 modern. Nelayan tradisional adalah nelayan yang menggunakan perahu kayu (sampan dayung) dan nelayan modern menggunakan perahu motor (sampan tempel) dalam operasi penangkapan ikan di perairan laut.

Data primer dikumpulkan dengan teknik wawancara mendalam yang dikombinasikan dengan pengamatan berperanserta terhadap 6 informan kunci. Data primer mencakup data bentuk-bentuk kerawanan dan strategi nafkah.

Teknik analisis data yang digunakan dalam penelitian ini adalah mengacu pada konsep Milles \& Huberman (1992) yaitu interactive model yang mengklasifikasikan analisis data dalam tiga langkah, yaitu: Reduksi data (Data Reduction), Penyajian data (Display Data) dan Penarikan kesimpulan (Verifikasi ). Untuk mendapatkan kevaliditasan data dalam penelitian ini, peneliti akan membandingkan data dari hasil pengamatan dengan hasil wawancara yang dilakukan terhadap informan kunci maupun responden kasus. Teori utama yang dipergunakan untuk menganalisis adalah teori ekonomi moral Scott (1983).

\section{HASIL DAN PEMBAHASAN}

\section{Bentuk-Bentuk Kerawanan Struktural Nelayan Sekunyit}

Ketidakmampuan nelayan untuk memanfaatkan sumberdaya secara optimal menjadi salah satu faktor yang mempengaruhi nelayan berada pada garis kemiskinan. Namun, hal itu hanya satu dari sekian banyaknya faktorfaktor yang menyebabkan kemiskinan terhadap nelayan Sekunyit. Berbagai bentuk kerawanan juga menjadi salah satu faktor yang menjadi penyebab kemiskinan terhadap nelayan. Kerawanan struktural ini terdiri dari tiga bentuk, yaitu kerawanan ekologis, kerawanan sistem harga, dan keseragaman sumberdaya.

\section{Kerawanan Ekologis}

Permasalahan cuaca dan musim merupakan faktor utama yang menentukan kegiatan nelayan. Cuaca buruk dalam jangka waktu yang cukup lama sangat mengganggu kegiatan nelayan dalam melaut. Mayoritas penduduk Sekunyit menggantungkan hidupnya terhadap sektor kelautan dan tidak memiliki pekerjaan lain selain melaut. 
Jika datang cuaca buruk kebanyakan dari nelayan hanya bisa berdiam diri di rumah sambil menunggu cuaca kembali baik. Dalam jangka waktu tersebut sebagian dari nelayan sama sekali tidak bekerja sehingga tidak memiliki pemasukan bagi rumah tangganya. Sebagai contoh, ilustrasi yang disampaikan oleh bapak SR berikut:

"aman datang ha'i jehat paling de pacak nengah, aw kadang thu nyampai seminggu kadangan sebulan payah nyaka' ha'i helau. Selame de nengah thu aw ape pule ke'eje, upahan man ade u'ang ngajak, man ndak ke'eje asing aw ke'eje ape pule, setue ni ke'eje awak di laut nilah jadi thu kebingungan man ndak ke'eje di da'at ne. Man de ade e ke'eje paling nunggu' di'umah nilah mampuslah mpuk de be tanci, de batu betah pusing, paling makan culik bacih man de be tanci adak thu gigiti ja'i nilah". (Wawancara Tanggal 29/03/2015). Cuaca buruk yang sering terjadi di komunitas nelayan Desa Sekunyit antaranya angin kencang, gelombang besar (laut 'ajuhan) dan angin puting beliung. Jika dilihat dari kondisi di lapangan, waktu yang dapat dihabiskan nelayan untuk beraktifitas di laut hanya berkisar delapan bulan, sementara empat bulan yang tersisa yaitu terhitung Bulan Juli, Agustus, September, Oktober bahkan menjelang Bulan Desember akan sering datang cuaca buruk. Dalam satu bulan sulit bagi nelayan untuk mendapati cuaca dalam keadaan baik. Cuaca buruk pernah menimbulkan musibah terhadap nelayan Sekunyit yang menyebabkan nelayan trauma untuk melaut kembali.

\section{Kerawanan Sistem Harga}

Harga menjadi salah satu permasalahan yang harus dihadapi nelayan dalam kegiatan pemasaran hasil tangkapan. Tidak adanya ketetapan harga secara pasti terhadap ikan hasil tangkapan nelayan sering menimbulkan kerugian bagi nelayan. Harga ikan dengan jenis dan ukuran yang sama dapat berbeda harganya dalam waktu satu hari.

Faktor utama yang mempengaruhi harga ikan dalam kasus nelayan Sekunyit adalah jumlah orang yang berminat membeli ikan tersebut. Semakin banyak orang yang bersaing untuk membeli ikan maka pihak penjual dapat menawarkan ikan dengan harga yang mahal dan begitu juga sebaliknya. Jika hanya sedikit yang berminat untuk membeli ikan tersebut maka pihak penjual tidak dapat menawarkan ikan dengan harga yang mahal karena kemungkinan ikan tersebut tidak akan laku. Sehingga terpaksa para petugas TPI yaitu nelayan atau orang biasa yang bekerja di TPI menjual ikan hasil tangkapan nelayan tersebut dengan harga yang murah. Sejauh ini nelayan menilai bahwa harga yang diterima dari penjualan hasil tangkapan mereka belum membuat nelayan merasa puas, karena kurang sebanding antara jenis ikan yang dijual dengan harga semestinya.

\section{Kerawanan Keseragaman Sumberdaya}

Keseragaman sumberdaya yang dimanfaatkan nelayan menyebabkan persaingan secara tidak langsung dalam kegiatan nelayan, terutama antara nelayan Sekunyit dengan nelayan yang datang dari luar daerah Sekunyit. 
Keseragaman sumberdaya yang dimanfaatkan nelayan pernah menimbulkan konflik dalam kehidupan nelayan.

Selain itu munculnya nelayan besar yang datang dari luar dengan menggunakan peralatan yang jauh lebih canggih memarginalkan posisi nelayan Sekunyit. Eksploitasi melalui alat tangkap modern menyebabkan semakin berkurangnya sumberdaya perikanan yang ada dan menurunkan pendapatan yang diperoleh nelayan.

\section{Strategi Nafkah Rumah Tangga Nelayan sebagai Strategi Bertahan Hidup}

Sejauh ini modernisasi telah menimbulkan sebuah bentuk kapitalisasi perikanan dengan adanya peningkatan terhadap penggunaan modal dan penggunaan berbagai alat tangkap baru yang mengakibatkan peningkatan terhadap pengeluaran rumah tangga nelayan. Nelayan modern lebih mampu berusaha secara optimal dalam memanfaatkan sumberdaya yang ada dibandingkan dengan nelayan tradisional.

Sebelum adanya modernisasi kegiatan strategi nafkah lebih banyak dilakukan penduduk Sekunyit terutama nelayan dengan memanfaatkan sumberdaya alam, seperti mengambil karang di lautan untuk dijadikan kapur, menebang kayu dan bertani. Namun, saat ini kegiatan strategi nafkah lebih banyak dilakukan nelayan dengan pemanfaatan di luar sumberdaya alam, seperti melakukan pekerjaan serabutan dan lainnya. Perubahan terhadap kondisi kehidupan nelayan akibat modernisasi telah menyebabkan peningkatan penggunaan terhadap modal kapital dan penurunan terhadap penggunaan modal tenaga kerja.

\section{Studi Kasus 1: Strategi Nafkah Rumah Tangga Nelayan Modern}

Penggunaan teknologi dalam komunitas nelayan Sekunyit semakin membuka peluang terhadap nelayan untuk memanfaatkan sumberdaya secara optimal. Dengan adanya penggunaan mesin dalam komunitas nelayan Sekunyit pada tahun 1977 telah memperlancar akses nelayan dalam melakukan kegiatan nafkahnya

Modernisasi yang terjadi dalam kehidupan nelayan Sekunyit telah menyebabkan peningkatan terhadap penggunaan modal uang. Selain itu modernisasi telah memberikan peluang terhadap nelayan luar untuk turut memanfaatkan sumberdaya perikananan yang ada di Sekunyit. Hal ini menyebabkan pendapatan nelayan kian fluktuatif. Selain disebabkan oleh berbagai kerawanan dalam sistem nafkahnya, nelayan juga harus dihadapkan dengan persaingan dalam pemanfaatan sumberdaya perikanan yang ada.

Pendapatan yang diperoleh nelayan Sekunyit hanya dapat digunakan untuk memenuhi kebutuhan sehari-hari, sulit bagi nelayan untuk mengakumulasikan pendapatannya ataupun mencoba menginvestasikan ke dalam bidang lainnya.

Bentuk strategi nafkah rumah tangga nelayan modern diuraikan sebagai berikut. 


\section{Pola Nafkah Ganda (diversifikasi pekerjaan)}

Pola nafkah ganda menjadi salah satu strategi andalan rumah tangga nelayan modern untuk menopang perekonomian keluarga. Upaya diversifikasi yang dapat dilakukan nelayan sangat tergantung terhadap peluang-peluang yang ada di dalam desa tersebut baik dengan memanfaatkan sumberdaya alam yang ada ataupun di luar dari pemanfaatan sumberdaya alam. Pola nafkah ganda dilakukan untuk mendiversifikasikan pendapatan dalam rumah tangga agar dapat memenuhi kebutuhan yang ada. Berikut bentuk-bentuk diversifikasi pekerjaan yang dilakukan rumah tangga nelayan modern Desa Sekunyit: menggarap sawah, berkebun kelapa, dan bekerja Serabutan

\section{Pelibatan Anggota Keluarga}

Sebelum adanya modernisasi keterlibatan anggota keluarga baik anak atau istri dalam mencari nafkah untuk membantu suami belum banyak dilakukan seperti kondisi saat ini. Istri hanya berperan sebagai ibu rumah tangga dan membantu bertani jika musim tanam tiba, setelah itu kegiatannya hanya dilakukan di rumah sebagai ibu rumah tangga biasa. Begitu juga halnya dengan peran anak, hanya sekedar membantu pekerjaan orang tuanya misalnya menarik sampan jika ayahnya pulang melaut atau membantu mencangkul ketika datang musim tanam.

Setelah adanya modernisasi dalam komunitas nelayan, hal ini menyebabkan peningkatan terhadap peluang kerja di luar sektor lain selain laut. Semakin terbukanya peluang kerja di luar sektor keluatan, hal ini menyebabkan banyak dari anggota keluarga yang bekerja dan terlibat dalam membantu mencari nafkah sebagai upaya agar dapat memenuhi kebutuhan hidup. Dengan adanya pelibatan anggota keluarga dalam mencari nafkah, hal ini secara langsung dapat meningkatkan ketahanan rumah tangga dalam menghadapi berbagai bentuk kerawanan yang dapat mengganggu kehidupannya.

Pelibatan anggota keluarga dalam mencari nafkah bagi rumah tangganya semata-mata dilakukan sebagai upaya menambah pendapatan rumah tangga agar dapat memenuhi semua kebutuhan untuk dapat bertahan hidup (survival stratergy). Tidak ada upaya untuk menginvestasikan atau mengakumulasikan pendapatan dari kegiatan tersebut.

\section{Pendayagunaan Jaringan Sosial dalam Menghadapi Masa Sulit}

Berbagai upaya yang dilakukan rumah tangga nelayan untuk memperkaya sumber pendapatan yang ada guna menopang perekonomian keluarga juga tidak mudah untuk dilakukan karena berbagai hambatan yang ada. Secara umum berbagai hambatan tersebut adalah terbatasnya peluang kerja yang ada, keterbatasan modal dan keterampilan nelayan untuk dapat mengakses pekerjaan lain di luar sektor kelautan. Oleh karena itu, memanfaatkan jaringan sosial merupakan salah satu strategi yang dapat diandalkan untuk mengatasi kesulitan ekonomi yaitu dengan memanfaatkan 168 | Lidia Yuliana, Septri W., dan Indra C., Strategi Nafkah Rumah Tangga... 
para bos-bos besar seperti juragan dan para bos tempat pelelangan ikan yang ada.

\section{Anak Merantau}

Kesulitan ekonomi yang dihadapi nelayan dalam kehidupannya merupakan salah satu faktor pendorong banyaknya anak nelayan yang merantau ke kota-kota besar untuk bekerja. Bahkan tidak jarang dari mereka yang tinggal menetap di kota perantauan tersebut. Mayoritas anak-anak yang pergi merantau tersebut adalah mereka yang baru lulus dari sekolah menengah atas dan tidak melanjutkan pendidikan ke jenjang perguruan tinggi. Dari pada berdiam diri di rumah, anak-anak tersebut lebih memilih untuk bekerja diperantauan sambil mencari pengalaman. Dengan adanya fenomena anak merantau tersebut sedikit mengurangi pengeluaran rumah tangga yang bersangkutan.

\section{Studi Kasus 2: Strategi Nafkah Rumah Tangga Nelayan Tradisional}

Permasalahan ekonomi merupakan faktor utama yang sering menghambat kehidupan nelayan untuk berkembang. Sejauh ini, bertahannya sebagian kecil komunitas nelayan Desa Sekunyit dalam sistem tradisional disebabkan oleh kurangnya modal. Dengan segala keterbatasan yang ada tersebut semakin mempersempit peluang nelayan tradisional untuk memanfaatkan sumberdaya yang dimiliki secara optimal.

Pada dasarnya modernisasi yang terjadi dalam komunitas nelayan Sekunyit semakin melemahkan posisi nelayan tradisional. Keterbatasan nelayan tradisional untuk bersaing dengan nelayan modern menjadi salah satu kesulitan yang harus dihadapi nelayan. Modernisasi yang terjadi belum bisa merubah keseluruhan nelayan menjadi nelayan yang modern dan maju. Modernisasi hanya dapat diikuti bagi nelayan yang memiliki modal, sementara nelayan tradisional yang terbatas terhadap modal kian tersingkir. Rumah tangga nelayan tradisional memiliki tingkat kesulitan yang lebih tinggi dibandingkan rumah tangga nelayan modern.

Terbatasnya akses dalam melaut yang dilakukan nelayan tradisional terutama terhadap zona penangkapan dan diversifikasi alat tangkap yang digunakan, akan menimbulkan pengaruh terhadap pendapatan yang diperoleh.

Pada umumnya bentuk strategi nafkah yang dilakukan nelayan tradisional dan modern relatif sama, yaitu pola nafkah ganda, pelibatan anggota keluarga, signifikansi jaringan sosial dan strategi menghadapi masa sulit. Berikut akan diuraikan pada pembahasan selanjutnya.

\section{Pola Nafkah Ganda (diversifikasi pekerjaan)}

Sejauh ini bentuk diversifikasi nafkah yang dilakukan nelayan modern dan nelayan tradisional mengalami perbedaan, mayoritas rumah tangga nelayan tradisional tidak menjadikan kegiatan bersawah menjadi salah satu 
bentuk strategi nafkah yang dapat diandalkan. Ketiadaan kepemilikan lahan sawah menyebabkan nelayan tidak bisa menggarap sawah. Namun bagi sebagian nelayan yang memiliki sawah mereka menjadikan kegiatan bersawah sebagai salah satu strategi nafkah yang dilakukan.

Berdasarkan penuturan salah seorang nelayan tradisional bernama bapak RS yang mengatakan bahwa:

“...seumu'-umu' kami bekeluarga, de nye kami besawah. Sawah kami di laut nilah. Luk mane ndak besawah, matik sawah saje dak ade e. Misal ndak makai sawah u'ang ai lah u'ung nhan batu, awak lah je'ih hasil e dikit same luk sie-sie saje. Acak di 'umah nilah ndai hanye je'ih i badan".

Bagi rumah tangga Pak RS kegiatan bersawah tidak pernah dilakukan sebagai salah satu bentuk strategi nafkah. Hal ini karena mereka tidak memiliki lahan sawah. Sementara jika bersawah dengan menggarap sawah orang lain hanya membuang waktu karena hasil yang didapat tidak sebanding dengan pengeluaran untuk biaya menggarap sawah. Oleh karena itu rumah tangga Pak RS enggan untuk melakukan kegiatan menggarap sawah sebagai salah satu strategi yang dilakukan.

Berbagai bentuk kerawanan yang terjadi dalam kehidupan nelayan Sekunyit juga menjadi salah satu faktor yang menyebabakan adanya upaya pola nafkah ganda dalam kehidupan nelayan, terutama kerawanan ekologi. Hal ini dilakukan sebagai salah satu strategi untuk bertahan hidup.

Diversifikasi yang dilakukan rumah tangga nelayan tradisional adalah bekerja sebagai karyawan TPI, memancing di pinggiran pantai, dan bekerja serabutan.

\section{Pelibatan Anggota Keluarga}

Dalam kehidupannya nelayan seringkali harus dihadapkan dengan berbagai bentuk kerentanan yang dapat mengganggu ketahanan nafkah yang ada, sehingga hal tersebut berdampak terhadap pendapatan yang akan digunakan untuk memenuhi kebutuhan ekonomi keluarga.

Setiap anggota keluarga harus memiliki rasa kepedulian terhadap kondisi perekonomian keluarga agar rumah tangga yang dibangun tersebut dapat terus bertahan. Oleh karena itu adanya pelibatan peran isteri dan anak dalam membantu mencari nafkah menjadi sebuah strategi yang dilakukan berbagai rumah tangga untuk menopang perekonomian keluarga.

Namun, sejauh ini berdasarkan data yang dihimpun dilapangan keterlibatan anggota keluarga lainnya terutama isteri dalam rumah tangga nelayan tradisional justru tidak ada. Berbeda dengan apa yang terjadi terhadap nelayan modern. Hal ini menjadi salah satu faktor penyebab lemahnya kondisi perekonomian rumah tangga nelayan tradisional karena potensi tenaga kerja yang ada dalam rumah tangga tidak dapat dimanfaatkan secara optimal untuk membantu menopang perekonomian keluarga.

Istri-istri nelayan tradisional semata-mata hanya berperan sebagai ibu rumah tangga biasa yang memiliki kewajiban untuk mengurus rumah dan anak-anak mereka. Aktivitas keseharian mereka hanya dihabiskan di rumah. 
Sementara anak-anak nelayan tradisional cukup berperan membantu meringankan beban perekonomian keluarga dengan bekerja di luar sektor kelautan. Jenis pekerjaan yang biasa dilakukan adalah bentuk kerja serabutan dan membuat batu bata, hasil yang didapat biasanya digunakan untuk memenuhi kebutuhan pribadi, jenis kegiatan tersebut banyak dilakukan oleh anak laki-laki. Besarnya pendapatan yang biasa didapat berkisar Rp 50.000 per hari. Sementara anak-anak perempuan hanya berada di rumah dan tidak bekerja.

\section{Pendayagunaan Jaringan Sosial dalam Menghadapi Masa Sulit}

Upaya diversifikasi pekerjaan dan pelibatan anggota keluarga lainnya dalam membantu mencari nafkah tidak tidak selalu berlangsung dengan baik. Tidak adanya peluang dan kurangnya keterampilan menjadi salah satu faktor penghambat yang ada. Dengan adanya berbagai keterbatasan tesebut semakin membuat batasan-batasan yang ada dalam rumah tangga nelayan untuk mengakses berbagai sumber pendapatan ekonom keluarga.

\section{Tabel 2. Strategi Nafkah Rumah Tangga Nelayan Modern dan Tradisional dan Fungsinya terhadap Ekonomi Rumah Tangga}

\begin{tabular}{|c|c|c|c|}
\hline \multirow{2}{*}{$\begin{array}{l}\text { Strategi } \\
\text { Nafkah }\end{array}$} & \multicolumn{2}{|c|}{ Tipe Rumah Tangga Nelayan } & \multirow{2}{*}{$\begin{array}{c}\text { Fungsi Terhadap } \\
\text { Ekonomi Rumah } \\
\text { Tangga }\end{array}$} \\
\hline & Tradisional & Modern & \\
\hline $\begin{array}{l}\text { Diversifikasi } \\
\text { pekerjaan }\end{array}$ & $\begin{array}{l}\text { Bersawah, } \\
\text { Memancing di } \\
\text { pinggiran laut } \\
\text { Serabutan Pegawai TPI }\end{array}$ & $\begin{array}{l}\text { Bersawah, berkebun } \\
\text { Membuat batu bata } \\
\text { Serabutan }\end{array}$ & $\begin{array}{l}\text { Mendiversifikasi } \\
\text { sumber pendapatan } \\
\text { rumah tangga }\end{array}$ \\
\hline $\begin{array}{l}\text { Peran anggota } \\
\text { keluarga }\end{array}$ & $\begin{array}{l}\text { Anak : Serabutan } \\
\text { Melaut }\end{array}$ & $\begin{array}{l}\text { Isteri : } \\
\text { - Upahan } \\
\text { - Berdagang } \\
\text { - Memboroh } \\
\text { - Arisan } \\
\text { Anak: } \\
\text { - Serabutan } \\
\text { - Membuat batu } \\
\text { bata } \\
\text { - Melaut }\end{array}$ & $\begin{array}{l}\text { Menambah } \\
\text { pendapatan rumah } \\
\text { tangga. }\end{array}$ \\
\hline $\begin{array}{l}\text { Jaringan sosial } \\
\text { dalam } \\
\text { menghadapi } \\
\text { masa sulit }\end{array}$ & $\begin{array}{l}\text { Memanfaatkan kerabat, } \\
\text { tetangga dan bos TPI } \\
\text { Koperasi }\end{array}$ & $\begin{array}{l}\text { Memanfaatkan } \\
\text { jaringan kekerabatan, } \\
\text { tetangga dan bos TPI }\end{array}$ & $\begin{array}{l}\text { Penopang } \\
\text { perekonomian rumah } \\
\text { tangga dalam } \\
\text { menghadapi masa } \\
\text { sulit. }\end{array}$ \\
\hline Anak Marantau & & Bekerja di Kota Besar & $\begin{array}{l}\text { Mengurangi } \\
\text { pengeluaran rumah } \\
\text { tangga. }\end{array}$ \\
\hline
\end{tabular}

Akibat dari adanya berbagai keterbatasan tersebut, memanfaatkan jaringan sosial yang ada menjadi salah satu pilihan yang diambil rumah tangga nelayan tradisional untuk menopang perekonomian keluarga. Seperti halnya nelayan modern sejauh ini bentuk pemanfaatan jaringan sosial yang 
biasa dilakukan adalah dengan melakukan kegiatan berhutang. Hal ini dijadikan masyarakat menjadi strategi terakhir yang dilakukan untuk menopang perekonomian keluarga.

Kagiatan berhutang biasanya dilakukan nelayan tradisional kepada para bos-bos TPI, keluarga dan koperasi. Bentuk pembayaran utang yang dilakukan terhadap bos-bos TPI tersebut dilakukan dengan memotong hasil tangkapan nelayan setiap harinya. Besaran uang yang dipinjam biasanya berkisar Rp 100.000 - Rp 200.000.

\section{Relasi Modernisasi Perikanan dan Strategi Nafkah}

Modernisasi yang terjadi dalam komunitas nelayan Sekunyit telah menyebabkan berbagai perubahan struktural terhadap nelayan terutama terhadap peningkatan penggunaan teknologi dan berbagai alat tangkap baru yang digunakan nelayan. Hal ini juga berpengaruh terhadap kondisi kehidupan nelayan di luar sektor keluatan. Rumah tangga nelayan belum bisa mengandalkan kehidupannya semata-mata dalam sektor kelautan. Ketidakpastian terhadap pendapatan setiap harinya menjadi salah satu faktor penyebab sulitnya nelayan untuk menggantungkan hidup semata-mata dalam sektor kelautan.

Dengan adanya fluktuasi terhadap pendapatan nelayan, menyebabkan nelayan melakukan strategi lain untuk memenuhi kebutuhan hidup keluarganya demi keberlangsungan hidup kedepannya. Saat ini pemanfaatan di luar sumberdaya alam sebagai salah satu strategi nafkah lebih banyak dilakukan dibandingkan dengan memanfaatkan sumberdaya alam yang ada.

Berikut akan disajikan bentuk strategi nafkah sebelum adanya modernisasi dan setelah adanya modernisasi dalam kehidupan nelayan Sekunyit (Gambar 1). 


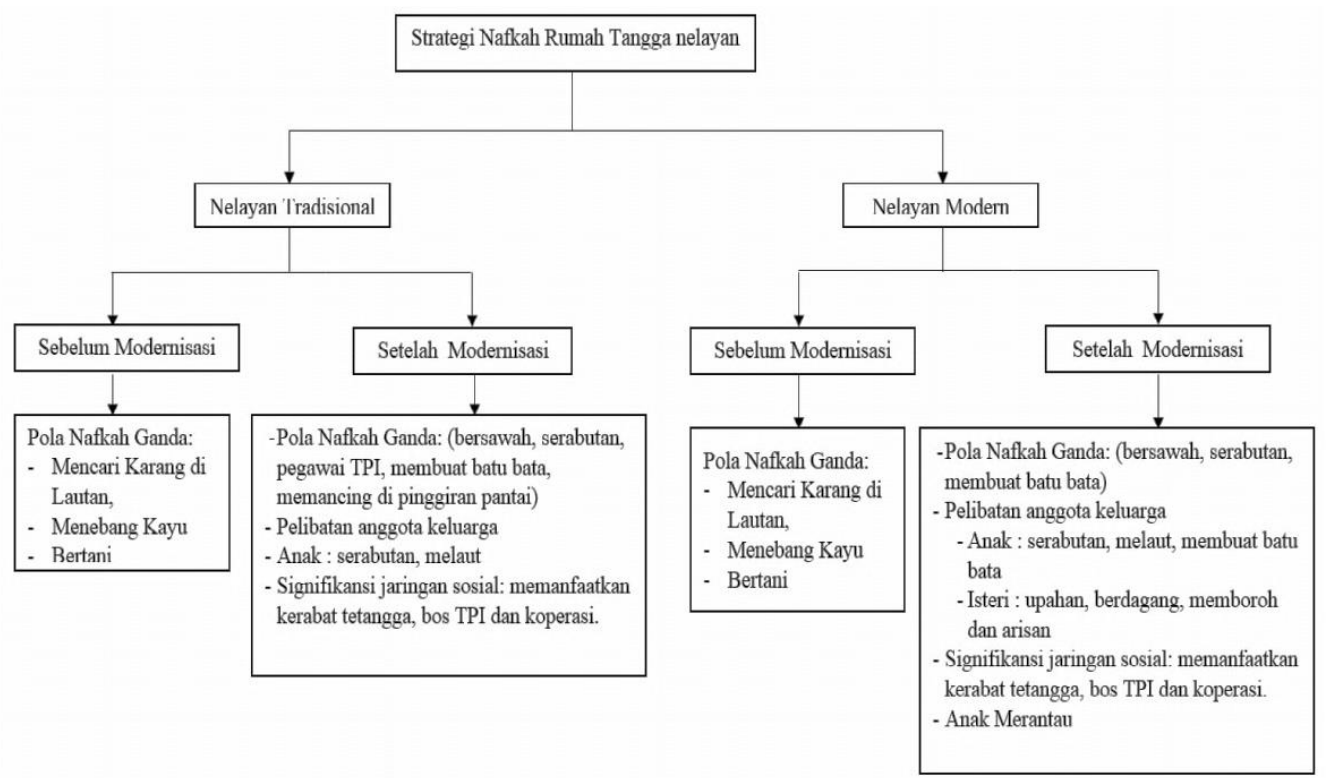

\section{Gambar 1. Bentuk Perubahan Strategi Nafkah Rumah Tangga Nelayan Sebelum dan Sesudah Modernisasi}


Berikutnya ini disajikan pelaku dalam kegiatan strategi nafkah terhadap rumah tangga nelayan.

Tabel 3. Strategi Nafkah Rumah Tangga Nelayan Tradisional dan Modern, Pelaku dan Polanya

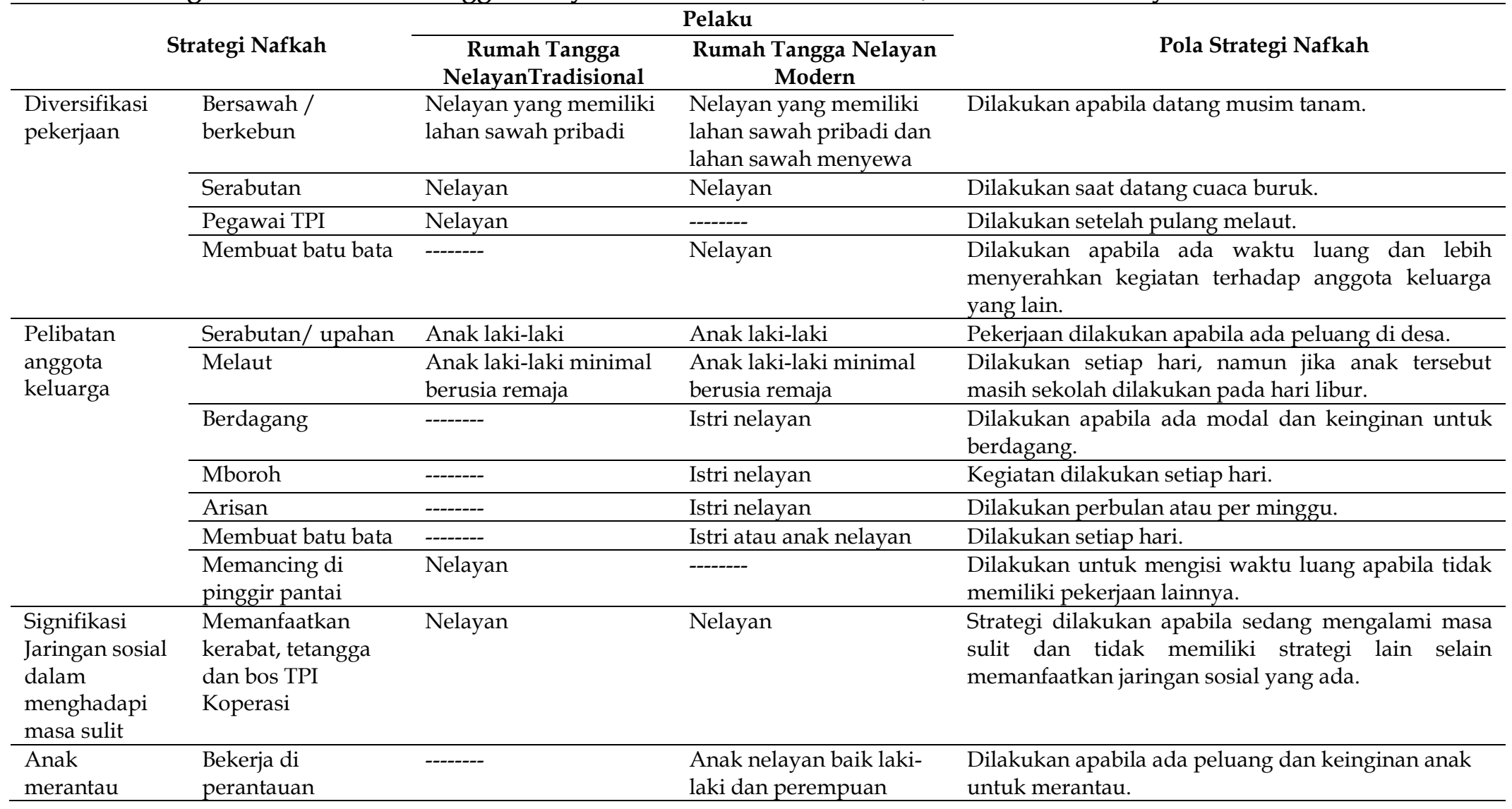

174 | Lidia Yuliana, Septri W., dan Indra C., Strategi Nafkah Rumah Tangga... 


\section{SIMPULAN}

\section{Simpulan}

Respon adaptasi strategi nafkah terhadap modernisasi terwujud dalam bentuk: pola nafkah ganda, pelibatan anggota keluarga, pendayagunaan jaringan sosial dalam menghadapi masa sulit, dan anak merantau. Keseluruhan dari strategi tersebut dilakukan rumah tangga nelayan sebagai upaya untuk bertahan hidup (survival strategy).

\section{DAFTAR PUSTAKA}

Arif, Adri. 2009. Modernisasi Perikanan; Apa Yang Terjadi?

https://www.scribd.com/doc/14684717/Modernisasi-Perikanan

Dinas Kelautan dan Perikanan Kabupaten Kaur. 2013.

Ellis, Frank. 2000. Rural Livelihood and Diversity in Developing Countries. Oxford University Press. New York.

Kusnadi. 2000. Nelayan: Strategi adaptasi dan Jaringan Sosial. Humaniora Utama Press. Bandung.

Satria, Arif. 2001. Dinamika Modernisasi Perikanan. Humanioria Utama Press. Bandung.

Schoorl J.W. 1984. Modernisasi: Pengantar Sosiologi Pembangunan NegaraNegara Berkembang. PT Gramedia. Jakarta.

Scott, J. 1983. Moral Ekonomi Petani. LP3ES. Jakarta.

Soekanto, S. 2003. Sosiologi Sebagai Suatu Pengantar. Rajagrafindo Press. Jakarta.

Mardianingsih, Dyah I., A.H. Dharmawan, Fredian Tonny. 2010. Dinamika Sistem Penghidupan Masyarakat Tani Tradisional Dan Modern Di Jawa Barat. Jurnal Sodality. Hal 149-181.

Miles M.B., dan Hubermen A.M. 1984. An Expended Source Book, Qualitative data Analysis. London: Sage Publication.

Widodo, Slamet. 2011. Strategi Nafkah Berkelanjutan Bagi Rumah Tangga Miskin Di Daerah Pesisir. Jurnal Makara Sosial Humaniora, 15 (1): 10-20.

Zid M. 2011. Fenomena Strategi Nafkah Keluarga Nelayan: Adaptasi Ekologis di Cikahuripan Cisolok Sukabumi. Jurnal Sosialita, 9 (1): 32-38. 
